\title{
Size-dependent competition in a gregarious porcelain crab Petrolisthes cinctipes (Anomura: Porcellanidae)
}

\author{
Megan J. Donahue* \\ Section of Evolution \& Ecology, Bodega Marine Laboratory, University of California, Davis, California 95616, USA \\ Present address: Department of Biological Sciences, Gilman Hall, Dartmouth College, Hanover, New Hampshire 03755, USA
}

\begin{abstract}
Studies of competition in benthic marine organisms have focused on sessile filter-feeders and mobile grazers, to the neglect of mobile filter-feeders, including porcelain crabs. The present study demonstrates intraspecific competition in Petrolisthes cinctipes (Randall) (Porcellanidae: Anomura). $P$. cinctipes settles gregariously and lives in high-density, multi-size aggregations. Studies of gregarious species often identify the benefits of aggregation without quantifying the concomitant costs; this study quantifies these costs. In field and laboratory experiments, $P$. cinctipes growth rates declined with increasing conspecific density and this decline was more severe for smaller individuals. $P$. cinctipes also fed less frequently at high density, and this effect was more pronounced for smaller individuals. This indicates that size-dependent agonistic interactions in $P$. cinctipes have effects on feeding rate and, ultimately, on growth rate. Resource levels were manipulated in laboratory experiments by using filtered and unfiltered seawater. The effect of resource level also depended on size: smaller crabs were more sensitive to changes in food level. Thus, conspecific density and food availability both affected growth rate in a size-dependent manner. Therefore, the costs of aggregation are more extreme for recruits than for adult crabs; recruits suffer more from competition, but may also benefit more if conspecific cueing results in settlement to sites with higher food availability.
\end{abstract}

KEY WORDS: Intraspecific competition · Size-dependent competition · Porcelain crab · Filter feeding · Gregarious settlement · Aggregation

Resale or republication not permitted without written consent of the publisher

\section{INTRODUCTION}

Studies of competition in marine systems have focused on 3 guilds that differ in mobility and feeding strategy. (1) Sessile, filter-feeding invertebrates of the rocky intertidal compete fiercely for space, resulting in radical changes in morphology and high mortality (Connell 1961, Bertness 1989, Wootton 1993, Bertness et al. 1998, Connolly \& Roughgarden 1998). (2) Among filter- or deposit-feeding, soft-bottom infauna with limited mobility, studies have demonstrated exploitative competition for food (Peterson 1982, Wenngren \& Olafsson 2002) and, occasionally, competition for space (Peterson \& Andre 1980). In contrast to sessile invertebrates of the rocky shore, competition among soft- bottom infauna typically results in decreased individual growth rate and fecundity, but rarely in mortality (Peterson \& Black 1993). Finally, (3) mobile grazers in the rocky intertidal or shallow subtidal (Menge 1976, Underwood et al. 1983, Branch 1984, Chow 1989, Schmitt 1996) usually compete exploitatively for food, resulting in decreased growth and fecundity.

Mobile filter-feeders, including many anomuran crabs and ophiuroids, fall between these guilds. Although mobile filter-feeders are abundant in many marine habitats, there has been little work on the presence and nature of competition in these organisms. Whereas studies on sessile filter-feeders have demonstrated competition for food (Peterson 1982, Cote et al. 1994) and space (Connell 1961, Bertness 1989, 
Bertness et al. 1998, Menge 2000), competition among mobile filter-feeders could be mitigated by movement. Increased mobility could also change the predominant mechanism of competition from interference competition for space to exploitative competition for food.

Behaviors that result in aggregation, like gregarious settlement, can enhance competition. Gregarious settlement is the preferential settlement in a patch with conspecifics over an equivalent patch without conspecifics (reviewed in: Burke 1986, Pawlik 1992). Researchers of gregarious settlement have proposed several benefits to this behavior (Burke 1986, Stamps 1988, Raimondi \& Keough 1990, Pawlik 1992, Krug \& Zimmer 2000, Toonen \& Pawlik 2001a), including (1) information about habitat quality (or 'habitat cueing') (Raimondi 1988, Jensen 1989, Muller et al. 1997, Mullineaux et al. 2000), (2) reduced risk of predation (Highsmith 1982, Tegner \& Levin 1983, Bertness \& Grosholz 1985, Jensen \& Armstrong 1991, Peterson \& Black 1993, Ray \& Stoner 1994), (3) facilitation (reduced suffocation risk: Bertness \& Grosholz 1985; reduced desiccation risk: Bertness 1989), and (4) access to mates (e.g. barnacle copulation: Burke 1986; fertilization of broadcast spawners: Metaxas et al. 2002). However, studies of gregarious species often identify the particular benefits of aggregation without quantifying the competitive costs.

Among the 3 benthic guilds for which competition is well studied, gregarious settlement is common among sessile filter-feeders and soft-bottom infauna (e.g. Bertness \& Grosholz 1985, Raimondi 1988, Nielsen \& Franz 1995, Minchinton 1997, Toonen \& Pawlik 2001b), but is rare among mobile grazers (Burke 1986). Among the mobile organisms that settle gregariously are a few snails (Burke 1986) and porcelain crabs, including Petrolisthes cinctipes (Jensen 1989, M. J. Donahue unpubl. data). Because sessile organisms choose a settlement site only once, settlement is a high risk event, which may select more strongly for gregariousness. For mobile organisms, the costs and benefits of aggregation seem less dramatic because immediate costs may be mitigated by movement. Despite this, $P$. cinctipes settles gregariously and individuals remain in high-density aggregations as adults. This pattern of aggregation in $P$. cinctipes, despite its mobility, might indicate that competition is weak.

Gregarious settlement can also lead to sizestructured interactions. In some organisms, arriving larvae are attracted to conspecific adults, resulting in multi-size aggregations; in others, e.g. barnacles (Bertness 1989), larvae settle gregariously with a cohort of other settlers. If competition is size dependent and settlement produces multi-size aggregations, then analysis of competition must take both size distribution and density into account (Werner \& Gilliam 1984). If different size-classes exploit different resources, then settlers will not compete with adults and the costs of gregarious settlement will be diminished. However, if the outcome of interference competition is determined by size, multi-size aggregations will have the opposite effect: juveniles will pay a high price for settling with larger conspecifics.

Resource availability can also change competitive interactions: high resource levels may decrease exploitative competition if the feeding apparatus is saturated, while low food levels may increase aggressive, interference interactions (Hazlett et al. 1975). Resource availability can affect small and large individuals differently, since small individuals are often more sensitive to low resource levels due to higher metabolic demands (Peters 1983). For filter-feeders, it is difficult to manipulate resource levels without adding unnatural food. In my experiments, I used filtered and unfiltered seawater as food treatments to maintain realism.

Using laboratory and field experiments, I estimated the effects of conspecific density, food availability, and size on individual growth and feeding rates in a mobile filter-feeder, Petrolisthes cinctipes. To connect these growth rates with fitness outcomes, I examined the relationship between body size and fecundity for P. cinctipes.

\section{MATERIALS AND METHODS}

Natural history and site description. Petrolisthes cinctipes lives in cobblefields and mussel beds from Point Conception, California, USA, to British Columbia, Canada (Morris et al. 1980). Adult P. cinctipes are highly aggregated, reaching densities of $950 \mathrm{~m}^{-2}$ (see Fig. 1). Megalopae settle preferentially with conspecifics over congeners, reinforcing the zonation of Petrolisthes species in the intertidal (Jensen 1989, Jensen \& Armstrong 1991). Megalopae are $\sim 1.5 \mathrm{~mm}$ in carapace width $(\mathrm{CW})$ at settlement, females are reproductive at $\sim 5 \mathrm{~mm} \mathrm{CW}$, and the maximum size of $P$. cinctipes is $\sim 20 \mathrm{~mm} \mathrm{CW}$.

Petrolisthes cinctipes move only when disturbed, and movement is size dependent: when a rock is turned, adults move quickly away, but recruits do not move at all (author's pers. obs., Jensen 1990). During both high and low tide, day and night, crabs can only be found under rocks and are never seen moving from rock to rock. A mark-recapture survey indicated that most $P$. cinctipes move very little $(<0.5 \mathrm{~m})$ in $24 \mathrm{~h}$, even after the disturbance of mark and release, although $1 \mathrm{crab}$ moved $8 \mathrm{~m}$ (author's unpubl. data). This shortterm survey matched the findings of Jensen (1990) and Jensen \& Armstrong (1991), who found that most $P$. cinctipes moved very little, but a few moved from 


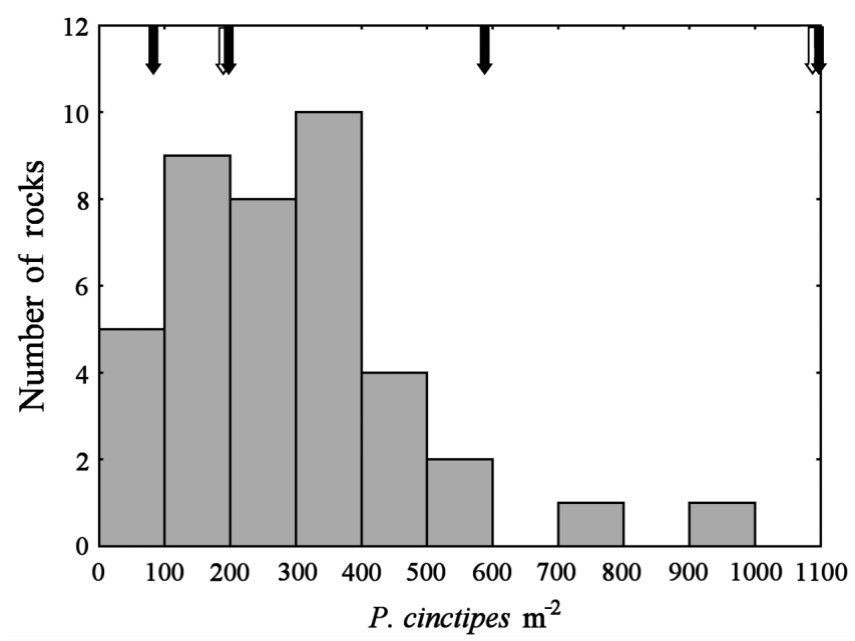

Fig. 1. Petrolisthes cinctipes. Histogram of crab density at Twin Coves: number of rocks (0.1 to $\left.0.15 \mathrm{~m}^{2}\right)$ with a given range of crab density. Solid arrows indicate the density treatments in the field experiment; open arrows indicate the density treatments in the laboratory experiment

10 to $20 \mathrm{~m}$ (out of an experimental patch into nearby habitat) over the course of a month.

The field experiment was performed at Twin Coves, a pair of small coves ( $0.5 \mathrm{~km}$ wide at the mouth) along a stretch of exposed coast in Sonoma County, California, USA $\left(38^{\circ} 27.517^{\prime} \mathrm{N}, 123^{\circ} 8.683^{\prime} \mathrm{W}\right)$. The intertidal area is a cobblefield; most cobbles are from 800 to $1600 \mathrm{~cm}^{2}$ (longest length by width) and are interspersed with large boulders.

Site survey. In March 2001, I performed a preliminary survey of Petrolisthes cinctipes density to determine an appropriate range of treatment densities. In August 2002, I conducted a more thorough survey of 40 rocks at Twin Coves. A $40 \mathrm{~m}$ transect was placed parallel to the shore at $\sim 0.2 \mathrm{~m}$ above MLLW, which is in the middle of the $P$. cinctipes zone. At $1 \mathrm{~m}$ intervals along the transect, the nearest rock of the target size (0.05-0.15 $\mathrm{m}^{2}$ ) was overturned into a plastic tub and all crabs $>0.2 \mathrm{~mm} \mathrm{CW}$ on or under the rock were collected and counted. Rocks below the target size were frequently tumbled by wave action and, consequently, $P$. cinctipes were rarely found underneath them. Rocks above the target size were too large and unwieldy to sample effectively, though they did have $P$. cinctipes underneath them. Habitable rock area was estimated using a piece of $\operatorname{Vexar}^{\circledR}$ mesh (mesh size $4.5 \mathrm{~cm}$ ) as a grid to measure the area of each rock in contact with the substrate.

Field experiment. To assess the impact of intraspecific competition on Petrolisthes cinctipes, I tracked the growth of crabs caged at different densities at Twin Coves. Each of 32 cylindrical cages was constructed from $25 \mathrm{~cm}$ diameter PVC pipe. A $10 \mathrm{~cm}$ length of pipe formed the base, the bottom of which was covered with Vexar mesh (mesh size $4.7 \mathrm{~mm}$ ); a $3 \mathrm{~cm}$ length of pipe formed the lid, the top of which was covered with mesh. The lid was secured to the base with cable ties, which allowed access to the cage without detaching the mesh. Three mesh-covered windows $(15 \times 6 \mathrm{~cm})$ in the base increased flow. The cages were haphazardly placed at least $3 \mathrm{~m}$ apart between 0.15 and $0.30 \mathrm{~m}$ above MLLW (mean low, low water), in the center of the $P$. cinctipes zone, each containing 3 small cobbles. Cage placement deliberately avoided tidepools or areas with standing water at low tide. It was often necessary to move several small cobbles to fit the cage snugly on the substrate (coarse sand and small rocks); this procedure assured that the rocks in the cage were at the same height as surrounding rocks and also prevented cages from being displaced by waves.

To evaluate the effect of density on growth rate, 5 crabs were tracked in each of 8 replicates of 4 density treatments, for a total of 32 cages. I collected, measured (CW) and wet weighed (after drying with Kimwipes) 160 Petrolisthes cinctipes sized 5.5 to $6.5 \mathrm{~mm}$ CW. Each crab was randomly assigned to one of 4 density treatments that fell within the range of densities measured in the field (Fig. 1), i.e. 5, 10, 30, 60 crabs $\operatorname{cage}^{-1}$; replicates of each treatment were randomly assigned to 8 cages. It is difficult to track crustacean growth for a long period since any tag on their carapace will be molted. Since this experiment was to run longer than a molt cycle for crabs of this size, I established the density treatments by adding larger crabs (>10 mm CW). Thus, if the tracked crabs molted and lost their tags, they could still be distinguished by size.

After $70 \mathrm{~d}$, I sampled the experiment by collecting the 5 tracked crabs from each cage and reweighing them. Most of the tracked crabs had molted and were indistinguishable from one another. Therefore, I calculated the average individual growth rate per day (AvgIGR) for the 5 crabs in each cage according to the formula:

$\operatorname{AvgIGR}=\frac{\frac{1}{5} \sum \ln W_{\text {final }}-\frac{1}{5} \sum \ln W_{\text {initial }}}{70 \mathrm{~d}}=\overline{\ln \left(W_{\text {final }} / W_{\text {initial }}\right)} / 70 \mathrm{~d}$

(where $W$ is crab biomass) and regressed this against density (STATISTICA 6.1, StatSoft 2002, available at www.statsoft.com). This response variable translates easily to growth equations and has a simple interpretation: the intercept of the regression is the relative growth rate in the absence of competitors and the slope is the decline in relative growth rate with each additional competitor.

Laboratory Expt I: effect of competition on growth rate. To assess the effects of food and density on the 
growth rate of 4 size-classes of crabs, I performed a laboratory experiment crossing 2 food levels by 2 densities. Each of these 4 treatments was replicated in eight 61 aquaria for a total of 32 aquaria. This experiment was run for $72 \mathrm{~d}$ (18 September to 29 November 2001) at the Bodega Marine Laboratory.

To maintain realism, I used raw and filtered seawater as the different food treatments (Lenihan et al. 1996), rather than adding an artificial food source that could dramatically change both food quantity and quality. Filtered seawater was processed through a sand filter, a $300 \mu \mathrm{m}$ filter bag, a settling tank, and (to ensure that food quality decreased, as well as particle size) a few hundred mussels; the raw water was unprocessed. This approach had the advantage that food components included only those in the field, but the disadvantage that food treatments were difficult to control and varied with the quality of intake water (see 'Sediment, organic matter, and chlorophyll in the laboratory and field'). Each water type was split through a manifold to flow into 16 aquaria; flow rates varied from 1 to $21 \mathrm{~min}^{-1}$ into each aquarium. Jensen (1990) and Molenock (1976) hypothesized that Petrolisthes spp. compete for high-quality feeding spots characterized by high flow. Therefore, each aquarium contained a half-brick, propped up $\sim 1 \mathrm{~cm}$ on one side; the incoming water was oriented underneath this brick to create variation in flow within the aquarium. To account for variation in flow across the manifold positions, aquarium placement was re-randomized every 3 to $4 \mathrm{~d}$ when the crabs were measured.

I designed the density treatments to correspond to the densities of 10 and 60 crabs cage $^{-1}$ found in the field experiment (Fig. 1). I collected crabs in 5 sizeclasses (A: 3.5 to $4.5 \mathrm{~mm}, \mathrm{~B}: 6.5$ to $7.5 \mathrm{~mm}, \mathrm{C}: 9.0$ to $11.0 \mathrm{~mm}, \mathrm{D}: 12.5$ to $14.5 \mathrm{~mm}, \mathrm{E}:>16.0 \mathrm{~mm})$ and imposed 2 density treatments at size-class ratios approximating those in the field. Low-density aquaria had 6 crabs in the ratio 2:2:1:1:0 (A:B:C:D:E); high-density aquaria had $35 \mathrm{crabs}$ in the ratio $12: 12: 5: 5: 1$. One individual in the largest size-class (>16 mm) was included in the high-density treatment to reflect size distributions in the field. However, this resulted in an unbalanced design, and this size-class was excluded from all analyses.

All crabs were marked with bee tags ('queen marking kit', The Bee Works), weighed, measured (CW), and randomly assigned to 1 of the 4 treatments (high/low density $\times$ high/low food). Every 3 to $4 \mathrm{~d}$ for $72 \mathrm{~d}$, each aquarium was cleaned and sampled; any individuals that had molted were remeasured, reweighed, and retagged. Any dead or missing crabs were noted and replaced.

At the end of the experiment, individual growth rate (IGR) per day was calculated for each crab: IGR = $\left[\ln \left(W_{\text {final }}\right)-\ln \left(W_{\text {initial }}\right)\right] /$ no. of days. The analysis used only the 487 crabs that had been in the aquarium for at least $36 \mathrm{~d}$ between initial and final measurements and had retained both chelipeds during that time. The 36-d cutoff balanced the need for a sufficient treatment exposure and inclusion of sufficient replicates of smaller crabs, because smaller crabs lost their chelipeds more frequently (see below). With this cutoff, there was no effect of the number of days in the experiment on either individual growth rate $(p>0.6)$ or ranked individual growth rate $(p>0.8)$ when added to the model below. To analyze the effect of density (D), food level (F), size-class (S), and aquarium (A) on IGR, I used the general linear model (GLM): IGR $\sim \mathrm{D}+\mathrm{F}+\mathrm{S}$ $+(\mathrm{D} \times \mathrm{F})+(\mathrm{D} \times \mathrm{S})+(\mathrm{F} \times \mathrm{S})+(\mathrm{D} \times \mathrm{F} \times \mathrm{S})+\mathrm{A}(\mathrm{D} \times \mathrm{F})+\varepsilon$, in which $A(D \times F)$ is the error term for $D, F$, and $D \times F$, and $\varepsilon$ is the error term for $\mathrm{S}, \mathrm{D} \times \mathrm{S}, \mathrm{F} \times \mathrm{S}$, and $\mathrm{D} \times \mathrm{F} \times \mathrm{S}$.

There was significant non-normality and heteroscedasticity in the data. I solved this by analyzing ranked IGR and using the natural logarithm of initial weight $\left(\ln W_{\text {initial }}\right)$ as a continuous variable instead of the categorical variable size (S). The residuals of the ranked, transformed model met the assumptions of normality and homogeneity of variance. There were no differences in the overall significance of the transformed model compared to the original model. I present significance values for the transformed, ranked model. However, to ease interpretation, the figures are plotted using IGR and categorized by size-classes. To understand the responses of different size-classes, I reanalyzed each size-class separately, using the model: $\mathrm{IGR} \sim \mathrm{D}+\mathrm{F}+(\mathrm{D} \times \mathrm{F})+\mathrm{A}(\mathrm{D} \times \mathrm{F})+\varepsilon$. Size-classes A, B, and $C$ met the assumptions, while $D$ remained heteroscedastic and the results should be considered with caution.

To compare the laboratory and field data, I regressed IGR versus numerical density for high- and low-food treatments separately using only Size-class B, which was closest in size to the crabs in the field experiment. I compared the intercepts (growth without competition) and slopes (competitive effect) between the highfood laboratory experiment, the low-food laboratory experiment, and the field experiment with $t$-tests.

Cheliped loss is another potential cost of agonistic interactions. Limb regrowth often results in a slowing of somatic growth and/or a decrease in fecundity and may decrease competitive ability (Juanes \& Smith 1995). Limb loss may also be size dependent, such that small individuals lose and regrow claws more easily than larger individuals (Juanes \& Smith 1995). To evaluate the size dependence of this behavior, I analyzed the frequency of limb loss in a logistic regression in which lost cheliped was the binomial response variable and food, density, and $\ln W_{\text {initial }}$ were predictor variables. These 3 variables and their interactions 
were evaluated with best subset model building, using likelihood ratio tests and the Akaike information criterion (Burnham \& Anderson 1998). The overall model fit is reported using $R_{L}^{2}$, which is the proportion of variation described in the best model compared to that described by the saturated model. Of 667 total crabs in the experiment, 85 crabs had lost a cheliped. Because of the relatively few cases of cheliped loss to consider, I did not test for an aquarium effect in this regression.

Petrolisthes spp. autotomize limbs very easily, suggesting that autotomy has a low cost for a filter-feeder that uses only modified maxillae for feeding (Wasson et al. 2002). Of the 85 crabs that lost a cheliped during the experiment, I had growth rates for 21 individuals both with and without the cheliped (i.e. the crab either lost its cheliped during the experiment or molted into a new cheliped during the experiment). Using a paired $t$-test, I tested for the effect of cheliped loss on IGR and on CW growth rate. If cheliped loss inhibits feeding (physically or due to competitive interactions), then both measures of growth rate should be negatively affected; if growth is reallocated to regrow the missing cheliped, then only the carapace growth rate should be negatively affected.

To more carefully examine the effects of food, density, and cheliped loss on growth rate, I restricted my analysis to Size A crabs, because most (57 out of 85 ) crabs that lost chelipeds were from Size-class A. I used a GLM with food, density, and cheliped loss as the main factors and density $\times$ cheliped loss and food $\times$ cheliped loss as crossed factors. I did not include food $x$ density or food $\times$ density $\times$ cheliped loss interactions, because of the low numbers of crabs with missing chelipeds in each treatment and because food $\times$ density was non-significant in the ANOVA on Size A crabs.

Sediment, organic matter, and chlorophyll in the laboratory and field. To estimate the effectiveness of the food treatments and to compare those food treatments to field conditions, I measured the percent organic matter and the amount of chlorophyll a (chl a) in water samples from the 2 food treatments and the field. On each of $2 \mathrm{~d}$, I collected three 11 samples each of laboratory-filtered seawater, laboratory-raw seawater, and Twin Coves seawater (collected on a rising tide in $\sim 1.5 \mathrm{~m}$ of water). The laboratory samples were collected and processed on the same day, but field samples were collected on another day (within a week of the laboratory samples); this was sufficient to see how laboratory treatments compared to food levels in the field. I filtered each sample to find the particulate matter in 3 fractions: 1 to $250 \mu \mathrm{m}, 250$ to $500 \mu \mathrm{m}$, and 500 to $1000 \mu \mathrm{m}$. For the 2 larger fractions, I filtered 11 of seawater through stacked sieves and rinsed the sieves with deionized water into pre-weighed drying tins. For the smallest fraction (1 to $250 \mu \mathrm{m})$, I filtered
$400 \mathrm{ml}$ through a $250 \mu \mathrm{m}$ sieve and then onto a preweighed, $1 \mu \mathrm{m}$ quantitative glass-fiber filter (GF/D). Each of these samples was dried, weighed, ashed, and reweighed for dry weight and ash-free dry weight. Dry weight and transformed percent organic matter were analyzed in a MANOVA, with day nested in seawater source and fraction (GLM module, STATISTICA 6.1, StatSoft 2002).

I also performed a fluorometric analysis of chl $a$ and phaeophytin. From each sample, I filtered $100 \mathrm{ml}$ of $<250 \mu \mathrm{m}$ filtrate onto $1 \mu \mathrm{m}$ quantitative glass-fiber filters (GF/D) and immediately froze them. To ensure that these measurements were comparable between days and water sources, all fluorometry was performed on a single day according to standard procedures with acetone (American Public Health Association 1995). I analyzed chl $a$ and phaeophytin $\left(\mu g \mathrm{l}^{-1}\right)$ in a MANOVA, with day nested in water source and fraction. Chl a was square-root transformed to meet the assumptions of MANOVA.

Laboratory Expt II: effect of density on feeding behavior. In order to understand the mechanism of competition, I tested how crab density affects feeding behavior. Using the same densities and size-class ratios as described in 'Laboratory Expt I', I set up 5 lowdensity and 5 high-density aquaria with individually marked crabs. To facilitate observations, these aquaria were placed in a different room from the competition experiment, where they could be seen from all sides. Because the experiment lasted for only 1 night and treatments could not be randomized across any flow differences, the aquaria were systematically interspersed along the manifold that divided seawater among treatments. Aquaria were supplied with filtered seawater, so there was no food treatment in this experiment; flow rates were from 1 to $21 \mathrm{~min}^{-1}$. The 2 density treatments were established $1 \mathrm{~d}$ previous to the start of the experiment to allow crabs to acclimate. Crabs are more active at night; therefore, I sampled the experiment 5 times from 1 afternoon until the next morning (every 3 to $4 \mathrm{~h}$ ), using a dim red light during the night samples. For each sample, I checked whether each crab was or was not feeding. I analyzed the fraction of observations in which each crab was seen feeding, $p$, as $\operatorname{Logit}(\mathrm{p}+0.5)=\mathrm{D}+\mathrm{S}+\mathrm{D} \times \mathrm{S}+\mathrm{A}(\mathrm{D})+\varepsilon$ and tested for effects of density, size, and aquarium, where aquarium was nested in density, plus the interaction of density and size. In addition to main effects, the comparisons of interest were across density within each size-class; these planned comparisons were tested using a Bonferroni adjustment for multiple comparisons.

Relationship between fecundity and biomass. The field and laboratory growth experiments were designed to test the effect of density on growth rate and resulting individual biomass. However, it is essential to 


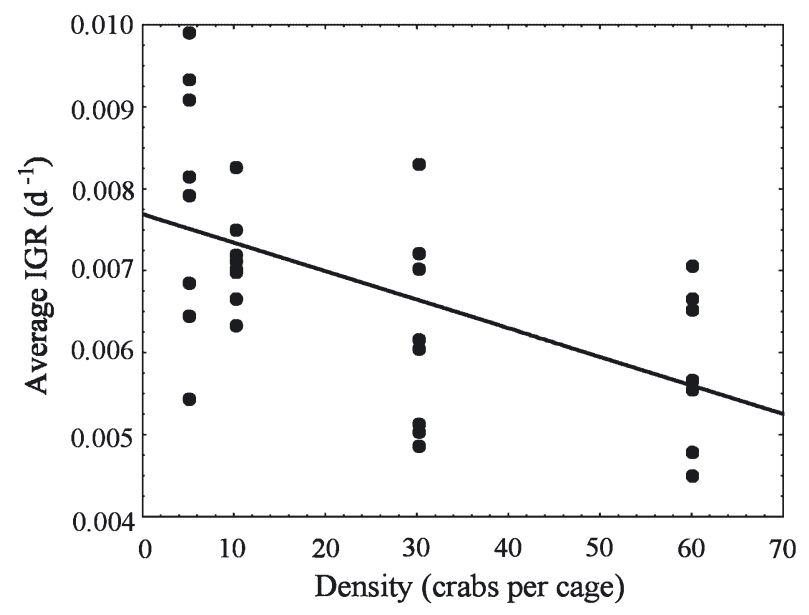

Fig. 2. Petrolisthes cinctipes. Average individual growth rate (IGR) from the field experiment. Average IGR is for the 5 tracked individuals in each cage; each point represents 1 cage. Overall regression is significant $\left(p=0.0007 ; R^{2}=0.32\right)$. Intercept of the regression $\left(\beta_{0}=7.5 \times 10^{-3} \pm 0.28 \times 10^{-3}\right.$ [SE], $\mathrm{p}<0.0001$ ) corresponds to the daily multiplicative growth rate in the absence of competition. Slope of the regression corresponds to the competitive effect of each crab added to the cage $\left(\beta_{1}=-3.5 \times 10^{-5} \pm 1.0 \times 10^{-5}[\mathrm{SE}], \mathrm{p}<0.001\right)$

connect biomass with fecundity to extrapolate from growth rate to population effects. In February 2001, I collected 182 ovigerous females from Twin Coves and 3 other cobblefields in Sonoma County (Salt Point, Timber Cove, and Fort Ross). From 37 crabs, I estimated the relationship between clutch size (number of eggs) and clutch dry weight $\left(\mathrm{R}^{2}=0.98, \mathrm{p} \ll 0.001\right.$, $0.104 \pm 0.005 \mathrm{mg} \mathrm{egg}^{-1} \pm 95 \% \mathrm{CI}$ ). I dried and weighed
Table 1. MANOVA on total dry weight and percent organic weight with seawater source, size fraction of particles, and day as factors

\begin{tabular}{|lrrrrcc|}
\hline Effect & Wilk's $\lambda$ & $F$ & $\mathrm{df}_{\text {effect }}$ & $\mathrm{df}_{\text {error }}$ & $\mathrm{p}$ \\
\hline Intercept & 0.0045 & 3516 & 2 & 32 & $<0.0001$ \\
Day (Source $\times$ Fraction) & 0.3694 & 2.3 & 18 & 64 & 0.008 \\
Source & 0.5508 & 5.6 & 4 & 64 & 0.0007 \\
Fraction & 0.0624 & 48.0 & 4 & 64 & $<0.0001$ \\
Source $\times$ Fraction & 0.5173 & 3.1 & 8 & 64 & 0.005 \\
\hline
\end{tabular}

the clutches of the remaining 145 crabs, calculated clutch size based on clutch dry weight, then estimated the relationship between crab biomass and clutch size using regression.

\section{RESULTS}

\section{Site survey}

Petrolisthes cinctipes is highly aggregated, with an average density of $294 \pm 30 \mathrm{~m}^{-2}$ (mean $\pm \mathrm{SE}$ ) and a maximum density of $950 \mathrm{~m}^{-2}$ (Fig. 1).

\section{Field experiment}

Average individual daily growth rate declined significantly with increasing density $\left(p<0.001, R^{2}=0.32\right.$; Fig. 2). The regression parameters can be used to estimate the effects of competition. The intercept of the
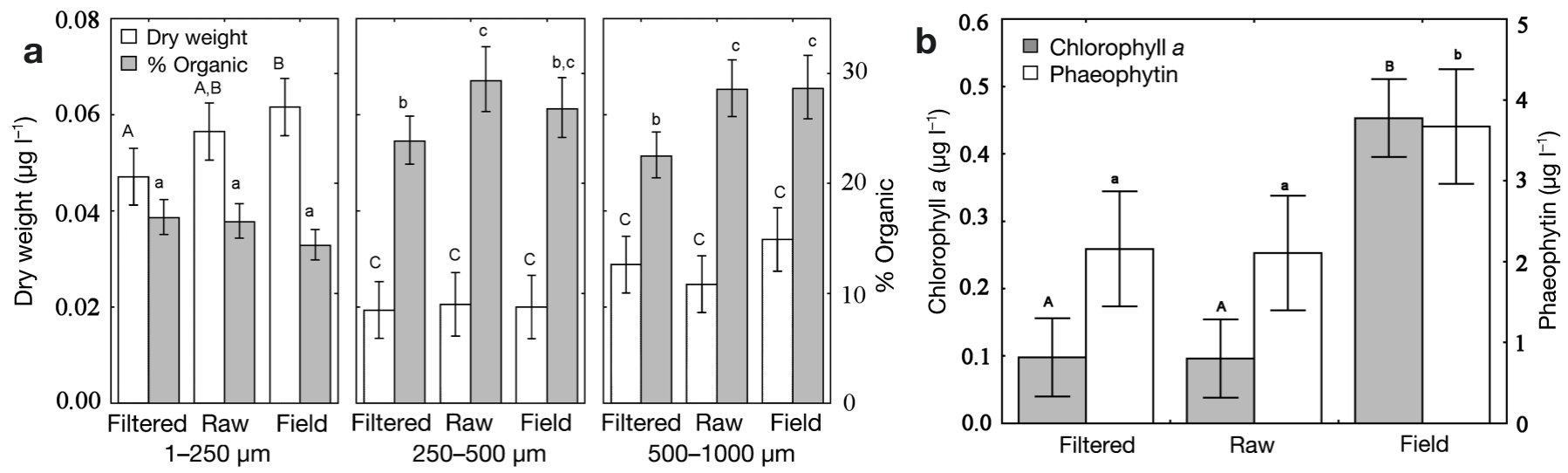

Fig. 3. Particulate matter, chlorophyll $a$, and phaeophytin in filtered, raw, and Twin Coves (field), seawater ( $\pm 95 \%$ CI). (a) Total dry weight is plotted on the left axis with open bars; upper-case letters indicated homogeneous groups (post hoc Tukey's HSD, $\mathrm{p}<0.05$ ). Back-transformed percent organic matter is plotted on the right axis with filled bars; lower-case letters indicate homogeneous groups (post hoc Tukey's HSD, $\mathrm{p}<0.05$ ). See Table 1 for results of MANOVA on total dry weight and percent organic matter. (b) Chl a concentration (left axis, filled bars, upper-case letters) and phaeophytin (right axis, open bars, lower-case letters) were higher in the field than in the laboratory (Wilk's $\lambda=0.11, p \ll 0.0001$ ). Letters indicated homogeneous groups (post hoc Tukey's HSD, p < 0.005) 
Table 2. General linear model of ranked individual growth rate with the continuous variable $\ln$ initial weight (In InitWt) and the factors food, density, and aquarium (aqua) nested in food $\times$ density. Aqua (food $\times$ density) is the error term for food, density, and food $\times$ density

\begin{tabular}{|lrrrrr|}
\hline Effect & \multicolumn{1}{c}{ SS } & df & \multicolumn{1}{c}{ MS } & $F$ & $p$ \\
\hline Intercept & 23227945 & 1 & 23227945 & 1490 & $<0.001$ \\
Aqua (Food $\times$ Density) & 391662 & 28 & 13988 & 0.899 & 0.617 \\
Food & 82602 & 1 & 82602 & 5.91 & 0.022 \\
Density & 863780 & 1 & 863780 & 61.8 & $<0.001$ \\
In Init Wt & 2613445 & 1 & 2613445 & 168.0 & $<0.001$ \\
Food $\times$ Density & 8870 & 1 & 8870 & 0.634 & 0.433 \\
Food $\times$ In Init Wt & 51963 & 1 & 51963 & 3.34 & 0.068 \\
Density $\times$ In Init Wt & 87221 & 1 & 87221 & 5.61 & 0.018 \\
Food $\times$ Density $\times$ In Init Wt & 2074 & 1 & 2074 & 0.133 & 0.715 \\
Error & 7017308 & 451 & 15559 & & \\
\hline
\end{tabular}

field samples to have higher food quantity than the filtered laboratory samples at small particle sizes, but higher food quality at large particle sizes.

\section{Laboratory Expt I: effect of density and food on growth rate}

IGR declined with density (Table 2, Fig. 4: Panels I \& II vs III \& IV) and increased with food level (Table 2, Fig. 4 Panels II \& IV vs I \& III). There was no effect of aquarium and no food $\times$ density or food $\times$ density $\times$ initial weight interactions (Table 2). Overall,

regression $\left(\beta_{0}=7.5 \times 10^{-3} \pm 0.28 \times 10^{-3}[\mathrm{SE}], \mathrm{p}<0.0001\right)$ corresponds to the daily relative growth rate in the absence of competition: $R=\mathrm{e}^{\beta_{0}}=1.008$. The slope of the regression corresponds to the competitive effect on relative growth rate of each additional crab in the enclosure $\left(\beta_{1}=-3.5 \times 10^{-5} \pm 1.0 \times 10^{-5}[\mathrm{SE}], \mathrm{p}<0.001\right)$.
IGR declined with initial weight, but there was a significant density $\times$ initial weight interaction and a marginally significant food $\times$ initial weight interaction (Table 2). Based on the individual size-class ANOVAs, the food $\times$ initial weight interaction arose because only Size-class B showed a marginally significant (Size B, $+22 \%$ ) increase in IGR with increased food (Table 3 ). The density $\times$ initial weight interaction arose because

\section{Sediment, organic matter, and chlorophyll in the laboratory and field}

Filtration to establish differing laboratory food treatments was only partially effective; percent organic matter was lower in filtered seawater compared to raw seawater for the 250 to $500 \mu \mathrm{m}$ and 500 to $1000 \mu \mathrm{m}$ fractions (Tukey's honest significant difference [HSD], p $<0.025$; Fig. 3a). However, there was no difference in total dry weight between raw and filtered seawater for any fraction (Table 1, Fig. 3a). There were also no differences in chl a or phaeophytin between the raw and filtered seawater (Fig. 3b). Overall, filtered seawater contained the same food quantity (total dry weight) as raw seawater, but lower food quality (percent organic weight) at larger particle sizes.

Field samples had higher levels of chl a and phaeophytin than did the laboratory samples (Fig. 3b). For small particle sizes, field samples had higher total dry weight than the filtered laboratory samples, but there was no difference for larger particle sizes (Fig. 3a). For large particle sizes, field samples had a higher percent organic matter compared to filtered seawater (Fig. 3a). Overall, the trend was for
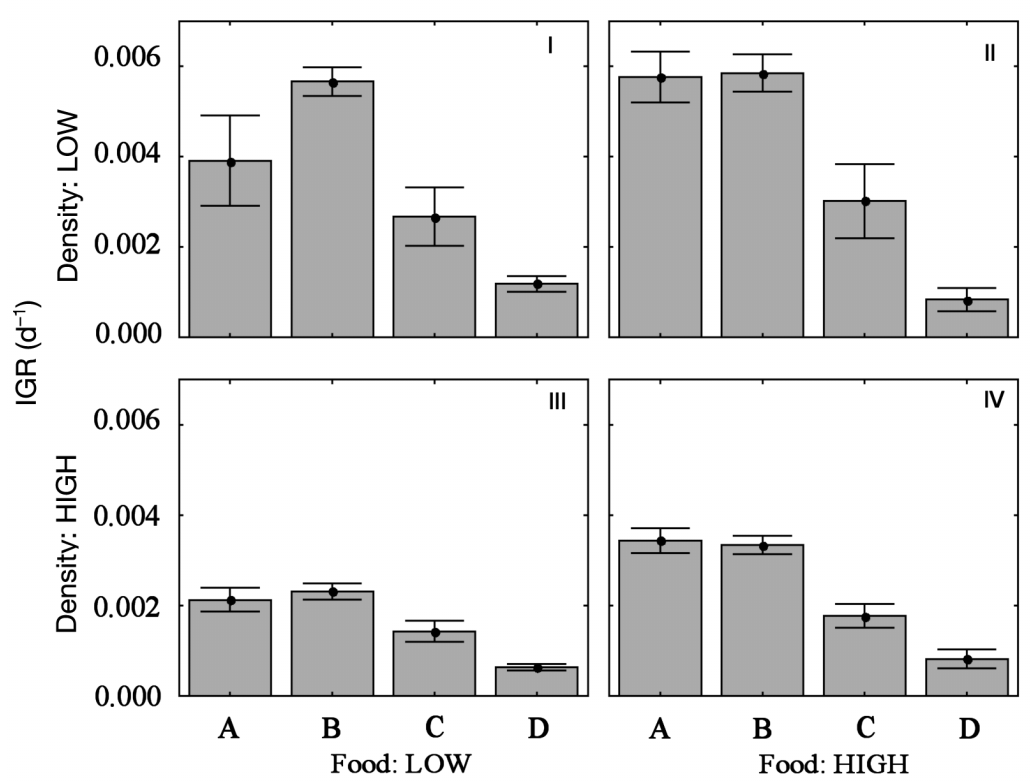

Fig. 4. Petrolisthes cinctipes. Individual growth rate by size-class, density, and food level from the laboratory experiment with standard error. There were significant declines in IGR with decreasing food (Panels II \& IV to I \& III) and with increasing density (Panels I \& II to III \& IV). There was a significant effect of initial weight (categorized here as A: 3.5 to $4.5 \mathrm{~mm}$, B: 6.5 to $7.5 \mathrm{~mm}, \mathrm{C}: 9.0$ to $11.0 \mathrm{~mm}$, D: 12.5 to $14.5 \mathrm{~mm}$ carapace width) and significant initial weight $\times$ food and initial weight $\times$ density interactions. IGR decreases with decreasing food for Size-classes A and, marginally, B; IGR decreases with increasing density for Size-classes A, B, and C 
Table 3. Separate ANOVAs on individual growth rate (IGR) within each size-class: IGR $\sim \mathrm{D}+\mathrm{F}+(\mathrm{D} \times \mathrm{F})+\mathrm{A}(\mathrm{D} \times \mathrm{F})$. There were no significant interactions between food and density and no significant effects of aquarium (Table 2). Effect sizes are the percent change in IGR from low to high levels of the given effect. The $F$-statistic and associated $p$-value are the main effects from each ANOVA. Size-class D did not meet the assumption of homoscedasticity

\begin{tabular}{|lcccc|}
\hline Effect & Size-class & Effect size (\%) & $F$ & $\mathrm{p}$ \\
\hline Food & $\mathrm{A}$ & 24 & 1.34 & 0.26 \\
& $\mathrm{~B}$ & 22 & 2.98 & 0.09 \\
& $\mathrm{C}$ & 9 & 0.29 & 0.6 \\
& $\mathrm{D}$ & 11 & 0.09 & 0.77 \\
Density & $\mathrm{A}$ & -47 & 16.1 & $<0.001$ \\
& $\mathrm{~B}$ & -51 & 76.4 & $<0.001$ \\
& $\mathrm{C}$ & -45 & 7.58 & 0.011 \\
& $\mathrm{D}$ & -29 & 1.38 & 0.25 \\
\hline
\end{tabular}

only Size-classes A $(-47 \%)$, B $(-51 \%)$, and C (-45\%) had significant declines with increasing density (Table 3).

The propensity to lose a cheliped was higher for smaller crabs (Likelihood Ratio Test [LRT], $\ln W_{\text {initial, }}$ p < 0.001) and, for these smaller crabs, the propensity to lose a cheliped was higher when food was scarce (LRT, food $\times \ln W_{\text {initial }}, \mathrm{p}=0.02$ ). The logistic regression model with $\ln W_{\text {initial }}$ and food $\times \ln W_{\text {initial }}$ was the best model by the Akaike information criterion; the overall regression accounted for $94 \%$ of the variance compared to the saturated model (i.e. $\mathrm{R}_{\mathrm{L}}^{2}=0.94$ ). For individual crabs, IGR was higher for a crab without its cheliped than with its cheliped (paired $t$-test, $\mathrm{p}=0.007$; Fig. 5); however, the growth in CW was marginally lower without its cheliped than with it (paired $t$-test, $\mathrm{p}=0.08$; Fig. 5). In the analysis of growth rate of Size A crabs, including
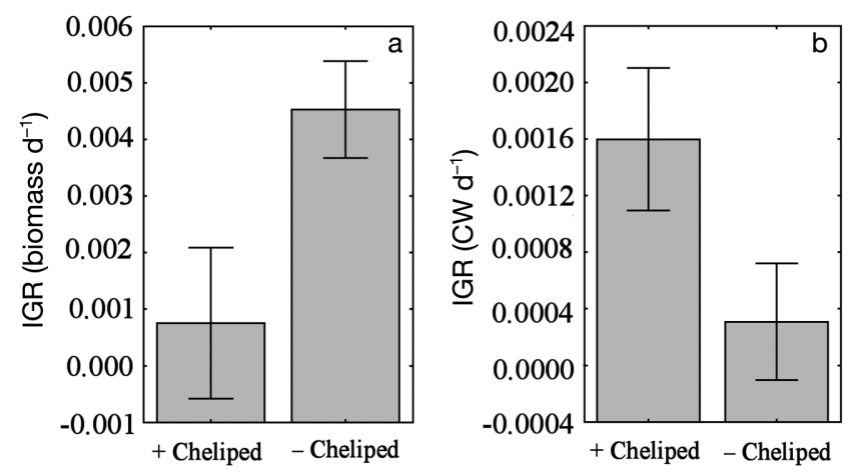

Fig. 5. Petrolisthes cinctipes. Paired comparisons of individual growth rate (IGR) in terms of (a) biomass and (b) carapace width (CW) with and without chelipeds in the laboratory growth experiment. There is a significant difference in biomass growth rate (paired $t$-test, $\mathrm{p}=0.007$ ) and a marginally significant difference in carapace width growth rate (paired $t$-test, $\mathrm{p}=0.08)$. Means and standard errors are plotted
Table 4. Comparison of individual growth rate (IGR) and competitive effect (decline in IGR per competitor) between highand low-food laboratory experiments and the field experiment. The laboratory data are for Size-class B only. Compared to either laboratory treatment, growth was higher ( $t$-test, $\mathrm{p}<$ $0.05)$ and competition was lower ( $t$-test, $\mathrm{p}<0.02)$ in the field. There is no difference between high- and low-food laboratory treatments for growth rate or competitive effect $(t$-test, $\mathrm{p}>0.2$ ). Note that all table values are $\times 10^{-3}$

\begin{tabular}{|lcc|}
\hline Experiment & $\begin{array}{c}\text { Growth rate } \\
(95 \% \text { CI) }(\text { without } \\
\left.\text { competitors } \times 10^{-3}\right)\end{array}$ & $\begin{array}{c}\text { Competitive effect } \\
(95 \% \text { CI) }(\text { per unit } \\
\left.\text { competitor } \times 10^{-3}\right)\end{array}$ \\
\hline Field & $7.69(0.64)$ & $-0.0349(0.0189)$ \\
Laboratory-high food & $6.368(1.21)$ & $-0.0865(0.0469)$ \\
Laboratory-low food & $6.353(0.93)$ & $-0.115(0.0372)$ \\
\hline
\end{tabular}

Table 5. Effects of size and density on frequency of feeding. Aqua (density) is the error term for density and size $\times$ density

\begin{tabular}{|lrrrrc|}
\hline Effect & SS & df & MS & $F$ & $\mathrm{p}$ \\
\hline Intercept & 10.77 & 1 & 10.77 & 31.82 & $<0.0001$ \\
Density & 4.83 & 1 & 4.83 & 5.92 & 0.041 \\
Aqua (Density) & 6.53 & 8 & 0.82 & 2.41 & 0.017 \\
Size & 3.07 & 3 & 1.02 & 3.03 & 0.031 \\
Size $\times$ Density & 0.34 & 3 & 0.11 & 0.14 & 0.935 \\
Error & 61.93 & 183 & 0.34 & & \\
& & & & & \\
\hline
\end{tabular}

those with lost chelipeds, IGR decreased with density (GLM, p < 0.001), similar to the analysis excluding crabs with lost chelipeds (Table 3 ). There was a marginally significant increase in IGR with food (GLM, $\mathrm{p}=$ 0.06), in contrast to the analysis that excluded crabs with lost chelipeds (Table 3). Cheliped loss also resulted in a marginally significant increase in growth rate (GLM, $p=0.06)$, similar to the results of the paired $t$-test. Density $\times$ cheliped loss and food $\times$ cheliped loss interactions were non-significant (GLM, p > 0.4).

\section{Comparison between laboratory and field results}

Compared to either laboratory treatment, growth was higher and competition was lower in the field (Table 4). There was no difference between high- and low-food laboratory treatments in growth rate or competitive effect (Table 4).

\section{Laboratory Expt II: effect of density on feeding behavior}

Crabs fed less frequently at high density (Table 5, Fig. 6), and smaller crabs fed less frequently than larger crabs (Table 5, Fig. 6). At high density, Size A 


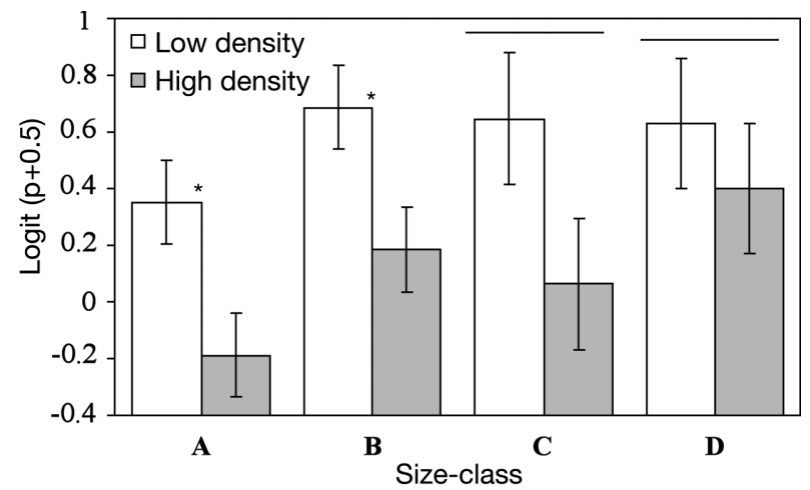

Fig. 6. Petrolisthes cinctipes. Feeding rate by density and size-class $( \pm \mathrm{SE})$. Feeding rate was lower for crabs at high density and increased with crab size (Table 5). * = signficant Bonferroni-adjusted planned comparisons across density within size, and horizontal lines indicate no significant difference between densities. Post hoc comparisons among sizeclasses indicated that Size-class A feeds significantly less than the other 3 size-classes (least significant difference $=$ LSD test,

$$
\mathrm{p}<0.04)
$$

crabs fed $66 \%$ less $(p=0.007)$ and Size B crabs fed $40 \%$ less $(p=0.012)$ than at low density (Fig. 6). Size C crabs fed $50 \%$ less at high density, but this difference was not significant ( $p=0.04$ : non-significant with Bonferroni correction). The $15 \%$ decrease in the feeding rate of Size D crabs at high density was also non-significant $(p=0.45)$. Because there were fewer crabs in Size-classes C and D, the power to detect an equivalent difference in feeding rate with density was lower (exact power calculations are difficult because of the unbalanced, nested design). The density $\times$ size interaction was non-significant $(p=0.8)$, but the power to

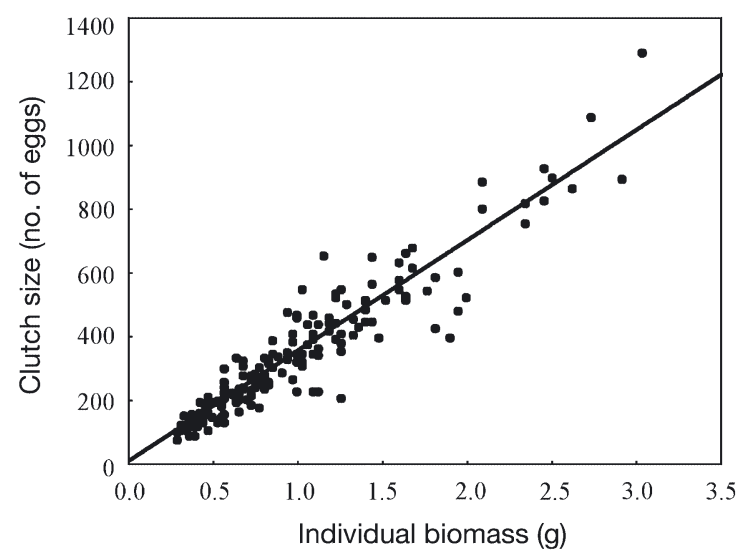

Fig. 7. Petrolisthes cinctipes. Fecundity as a function of wet biomass. Fecundity increased significantly with individual biomass $\left(R^{2}=0.89, p \ll 0.0001\right)$. The intercept was not significantly different from zero and the slope equalled 346 eggs $\mathrm{g}^{-1}$. Crabs were collected in February 2001 from 4 cobblefield sites in Sonoma County, CA, USA detect such an interaction was low $(<0.30)$. There was a significant aquarium effect in this experiment $\left(F_{8,183}=\right.$ $2.4, \mathrm{p}=0.017)$; the feeding rate was related to aquarium placement on the manifold and tended to be higher in higher flow aquaria. The effects of flow rate on the feeding behavior of filter-feeders has been documented in several studies (Sanford et al. 1994, Achituv \& Pedrotti 1999, Genovese \& Witman 1999). The laboratory growth-rate experiment took place in another facility with less variable flow, and I randomized aquaria across the manifold every 3 to $4 \mathrm{~d}$ to avoid these systematic effects.

\section{Relationship between biomass and fecundity}

Crab biomass was an excellent predictor of crab fecundity $\left(\mathrm{R}^{2}=0.89, \mathrm{p} \ll 0.001\right.$; Fig. 7$)$; the intercept was not significantly different from zero. Once it reaches

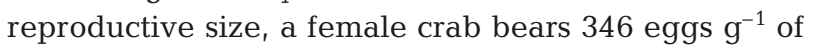
biomass.

\section{DISCUSSION}

In both the laboratory and the field, Petrolisthes cinctipes is negatively affected by conspecific density (Figs. 2 \& 4). Extrapolating from the daily growth rates in the field, a $5.5 \mathrm{~mm}$ crab will grow to $14.2 \mathrm{~mm}$ (95\% CI: $13.1,15.3)$ by the next year without competitors, but only to $11.0 \mathrm{~mm}(95 \% \mathrm{CI}$ : 10.3, 11.6) with 60 competitors, equivalent to high-density rocks in the field. This has a striking effect on fecundity (Fig. 7): the lone crab will bear 1080 eggs (95\%CI: 853, 1363), whereas the crowded crab will bear only 503 (95\% CI: $420,601)$.

\section{Size-specific effects of density and food}

The overall effect of density on IGR decreased with size (Fig. 4, Table 3). Small crabs may be more strongly affected by agonistic interactions than large crabs; this is supported by the decreasing effect of density on feeding rate with size (Fig. 6) and by the increased tendency for smaller crabs to lose chelipeds. Molenock (1976) found that size was a determining factor in agonistic interactions: for a pair of interacting Petrolisthes cinctipes, the larger crab usually initiated the interaction and the larger crab won space in $>70 \%$ of interactions.

Size also mediated the effect of resource availability on growth rate: smaller crabs suffered more from low food levels (Table 3, Fig. 4). Smaller organisms have higher metabolic demand per unit biomass than larger 
organisms and may be more sensitive to changes in food level (Peters 1983). Comparing density effect (change in IGR due to density) to food effect (change in IGR due to food) showed that the growth rates of Size A, B, C, and D crabs were $2.9-, 3.5-, 8.0-$, and 3.2 -fold more affected by density than food. The stronger effect of density than food in this experiment is not surprising, because density was increased 6 -fold, while the food treatment decreased food quality (percent organic matter) by only $\sim 10 \%$. However, food does seem to be important in cheliped loss: low food increased the probability of cheliped loss in small crabs and food had a marginally significant effect on growth rate when the analysis included crabs missing chelipeds.

There was no significant interaction between food level and density in the laboratory experiment (Table 2, Fig. 4), though the power to detect such an interaction was low. Regardless, it would not be correct to infer that competition is generally unaffected by resource level, because competition decreases with increasing size. For example, in a low-food year, newly settled crabs will grow more slowly and therefore suffer from stronger competition for a longer period. In a good-food year, however, a newly settled crab may quickly grow to a size where the competition it suffers is reduced.

Another indirect interaction between food and density may be mediated by limb loss. For small crabs, the prevalence of limb loss is higher when food is low. Though crabs seem to compensate for limb loss by increasing growth rate, this additional growth is allocated to limb replacement and not to an increase in carapace width (Fig. 5). Crabs that have lost chelipeds may take longer to outgrow size dependent competitive effects. Wasson et al. (2002) demonstrate the effectiveness of autotomy for predator avoidance in Petrolisthes spp. They also suggest that filter-feeders may have lower costs to autotomy, because they do not use their chelipeds to feed. The present study gives merit to the Wasson et al. (2002) hypothesis: P. cinctipes grew faster when a cheliped was missing, possibly indicating an increase in food intake, which could hasten cheliped regrowth. However, cheliped loss is not without costs, since it slows carapace growth.

\section{Comparing exploitative and interference competition}

Several studies have partitioned the relative effects of exploitative and interference competition (Anholt 1990, Fradkin 1995, Schmitt 1996, Josefson 1998). These effects cannot be strictly distinguished from these experiments, but some conclusions seem reason- able. In this study (author's pers. obs.) and in that of Jensen (1990), crabs appeared to congregate in areas of high flow in the aquarium and vie for position using the agonistic behaviors described by Molenock (1976). Several studies have demonstrated that flow rate affects feeding behavior and feeding efficiency in porcelain crabs (Trager et al. 1992, Trager \& Genin 1993, Achituv \& Pedrotti 1999) and in barnacles (Trager et al. 1992, 1994, Sanford et al. 1994). Since feeding efficiency varies with flow rate, crabs may be competing for good filter-feeding locations.

However, the decline in feeding rate with density is also consistent with exploitative competition. Many filter-feeders increase their feeding rate with food availability (Sanford et al. 1994), and Hartman \& Hartman (1977) found a positive relationship between the concentration of amino acids in seawater and the number of Petrolisthes cinctipes feeding. If crabs reduce their resources by feeding, then the decrease in feeding rate could simply be a response to lower food levels imposed by higher density. This is possible but seems unlikely since the high flow rate into the aquaria (1 to $21 \mathrm{~min}^{-1}$ ) should have greatly exceeded the ability of $P$. cinctipes to draw down its resources. Achituv \& Pedrotti (1999) found a maximum clearance rate of $0.286 \mathrm{l} \mathrm{crab}^{-1} \mathrm{~h}^{-1}$ for Porcellana longicornis (Anomura: Porcellanidae) clearing an algal suspension. While exploitative and interference mechanisms for the decline in feeding rate with density are not mutually exclusive, the interference mechanisms are probably stronger in this case.

\section{Comparing competition between the laboratory and field}

Competitive effects were generally lower in the field than in the laboratory. There are many possible explanations for this, including: (1) food availability, (2) size differences between laboratory and field crabs, (3) changes due to captivity, (4) size-structured interactions, and (5) complexity of the environment. (1) Overall food levels were higher in the field than in the laboratory, which could have resulted in decreased exploitative competition or aggressive interference interactions. Though there was no overall interaction between food availability and competition in the laboratory experiment (Table 2), the growth rate of Size B crabs was more strongly affected by density when food was low than when food was high (Fig. 4). For this sizeclass (which was most similar to that in the field), the higher food levels in the field could have mitigated the effects of competition. (2) Crabs in the field experiment were $\sim 1 \mathrm{~mm}$ CW smaller than laboratory Size-class B. Since the relative effect of density increased from Size 
A to Size B in the laboratory experiment (Table 3), this could help explain the stronger competition in the laboratory. (3) Crab behavior or physiology might have changed due to captivity in the laboratory experiment (Houlihan \& Mathers 1985). However, this would generally be expected to decrease aggressive interactions as physical performance declines in captivity. (4) Sizestructured interactions should have increased, rather than decreased, competitive effects in the field compared to the laboratory, since larger crabs were used to impose the field density treatments. Finally, (5) the laboratory aquaria, with a single half-brick and single inflow tube per aquarium, provided a less complex environment than the field cages. The cages were filled with 3 cobbles and probably had more high-flow spots than did the aquaria. This may have resulted in a stronger competitive hierarchy in the laboratory aquaria than in the field enclosures. Overall, higher food availability in the field (Fig. 3) and increased habitat complexity in field cages compared to aquaria are the most likely causes for decreased competition in the field compared to the laboratory.

\section{Trade offs related to gregarious settlement}

Petrolisthes cinctipes megalopae settle gregariously as incoming megalopae (Jensen \& Armstrong 1991, M. J. Donahue unpubl. data) and the adults are highly aggregated as adults (Fig. 1). Although they compete strongly (Figs. $2 \& 4$ ), there are also benefits to gregarious settlement, including habitat cueing (Raimondi 1988, Jensen 1989, Muller et al. 1997, Mullineaux et al. 2000), reduced predation risk (Highsmith 1982, Tegner \& Levin 1983, Bertness \& Grosholz 1985, Jensen \& Armstrong 1991, Peterson \& Black 1993, Ray \& Stoner 1994), facilitation (Bertness \& Grosholz 1985, Bertness 1989), and access to mates (Burke 1986, Metaxas et al. 2002). In addition, Jensen \& Armstrong (1991) showed that adult $P$. cinctipes protected settlers from predation by intertidal fishes and that, by settling with conspecifics, $P$. cinctipes settlers choose habitat preferred by adults. In another study (M. J. Donahue unpubl. data), I quantitatively compare the costs and benefits accrued to gregariously settling $P$. cinctipes and demonstrate that the competitive costs of settling with adults can be offset only when benefits include both decreased predation and increased habitat quality.

\section{CONCLUSIONS}

At first glance, Petrolisthes cinctipes would not seem to compete strongly: it settles gregariously, lives awash in its food, and is mobile. This study demonstrates that, despite these characteristics, competition is an important feature in the life history of $P$. cinctipes. Competition among filter-feeders has been well documented for space-limited sessile invertebrates (reviewed in Branch 1984) and for soft-bottom infauna (e.g. Peterson \& Andre 1980, Peterson 1982), but the present study draws new attention to mobile filter-feeders such as $P$. cinctipes.

Petrolisthes cinctipes densities vary widely from rock-to-rock within cobblefield sites (Fig. 1) and from site-to-site (M. J. Donahue unpubl. data). This spatial variation in density means that not all crabs experience the same level of competition. A site that receives high larval supply due to coastal features (Wing et al. 1995, 1998a,b) may have diminished fecundity due to intense post-settlement competition that decreases the growth rate. This interaction between spatially varying larval supply and post-settlement density dependence can influence the dynamics and stability of metapopulations (Chesson 1998). When considering P. cinctipes dynamics on the metapopulation scale, aggregation has an overall negative effect on crab growth rate due to competition, but a positive effect on local recruitment due to gregarious settlement and decreased predation. Future work will focus on how intraspecific competition in $P$. cinctipes, as demonstrated in this study, interacts with spatial variation in density to influence local and regional dynamics.

Acknowledgements. Thanks to the Bodega Marine Laboratory for aquarium and work space, especially to K. Menard and the ARG staff, who saved my crabs more than once. Thanks to L. Akins, N. Rayl, S. Jorgensen, and W. Trowbridge for help with field and laboratory experiments and to Troup 135 for help building cages. I had valuable discussions on this work with S. Morgan and P. Chesson. M. Watnik from the UC Davis Statistics Laboratory provided statistical advice. P. Chesson, S. Morgan, M. Holyoak, S. Gilman, C. Thornber, and 2 anonymous reviewers provided constructive input on earlier drafts of this manuscript. This research was conducted with support from the American Association of University Women, the Bodega Marine Laboratory, the UC Davis Center for Population Biology, and NSF DBI-9602226 (Research Training Grant for Nonlinear Dynamics in Biology) awarded to the University of California, Davis. This paper was submitted in partial fulfillment of the requirements of my doctoral dissertation at University of California, Davis.

\section{LITERATURE CITED}

Achituv Y, Pedrotti ML (1999) Costs and gains of porcelain crab suspension feeding in different flow conditions. Mar Ecol Prog Ser 184:161-169

American Public Health Association (1995) Standard methods for the examination of water and wastewater, 19th edn. American Public Health Association, Washington, DC

Anholt BR (1990) An experimental separation of interference and exploitative competition in a larval damselfly. Ecology 71:1483-1493 
Bertness MD (1989) Intraspecific competition and facilitation in a northern acorn barnacle population. Ecology 70 : 257-268

Bertness MD, Grosholz E (1985) Population dynamics of the ribbed mussel, Geukensia demissa: the costs and benefits of an aggregated distribution. Oecologia 67:192-204

Bertness MD, Gaines SD, Yeh SM (1998) Making mountains out of barnacles: the dynamics of acorn barnacle hummocking. Ecology 79:1382-1394

Branch GM (1984) Competition between marine organisms: ecological and evolutionary implications. Annu Rev Oceanogr Mar Biol 22:429-593

Burke RD (1986) Pheromones and the gregarious settlement of marine invertebrate larvae. Bull Mar Sci 39:323-331

Burnham KP, Anderson DR (1998) Model selection and inference: a practical information-theoretic approach. Springer-Verlag, New York

Chesson P (1998) Recruitment limitation: a theoretical perspective. Aust J Ecol 23:234-240

Chow V (1989) Intraspecific competition in a fluctuating population of Littorina plena Gould (Gastropoda: Prosobranchia). J Exp Mar Biol Ecol 130:147-166

Connell JH (1961) The influence of interspecific competition and other factors on the distribution of the barnacle Chthamalus stellatus. Ecology 42:710-723

Connolly SR, Roughgarden J (1998) A latitudinal gradient in Northeast Pacific intertidal community structure: evidence for an oceanographically based synthesis of marine community theory. Am Nat 151:311-326

Cote J, Himmelman JH, Claereboudt MR (1994) Separating effects of limited food and space on growth of the giant scallop Placopecten magellanicus in suspended culture. Mar Ecol Prog Ser 106:85-91

Fradkin SC (1995) Effects of interference and exploitative competition from large-bodied cladocerans on rotifer community structure. Hydrobiologia 313/314:387-393

Genovese SJ, Witman JD (1999) Interactive effects of flow speed and particle concentration on growth rates of an active suspension feeder. Limnol Oceanogr 44:1120-1131

Hartman HB, Hartman MS (1977) The stimulation of filter feeding in the porcelain crab Petrolisthes cinctipes (Randall) by amino acids and sugars. Comp Biochem Physiol 56:19-22

Hazlett BA, Rubenstein D, Rittschof D (1975) Starvation, energy reserves, and aggression in the crayfish Orconectes virilis (Hagen, 1870) (Decapoda, Cambaridae). Crustaceana 28:11-16

Highsmith RC (1982) Induced settlement and metamorphosis of sand dollar Dendraster excentricus larvae in predatorfree sites: adult sand dollar beds. Ecology 63:329-337

Houlihan DF, Mathers E (1985) Effects of captivity and exercise on the energetics of locomotion and muscle of Carcinus maenas (L.). J Exp Mar Biol Ecol 92:125-142

Jensen GC (1989) Gregarious settlement by megalopae of the porcelain crabs Petrolisthes cinctipes (Randall) and Petrolisthes eriomerus (Stimpson). J Exp Mar Biol Ecol 131:223-232

Jensen GC (1990) Intertidal zonation of porcelain crabs: resource partitioning and the role of selective settlement. PhD thesis, University of Washington, Seattle

Jensen GC, Armstrong DA (1991) Intertidal zonation among congeners: factors regulating distribution of porcelain crabs Petrolisthes spp. (Anomura: Porcellanidae). Mar Ecol Prog Ser 73:47-60

Josefson AB (1998) Resource limitation in marine soft sediments-differential effects of food and space in the association between the brittle-star Amphiura filiformis and the bivalve Mysella bidentata? Hydrobiologia 376: 297-305

Juanes F, Smith LD (1995) The ecological consequences of limb damage and loss in decapod crustaceans: a review and prospectus. J Exp Mar Biol Ecol 193:197-223

Krug PJ, Zimmer RK (2000) Larval settlement: chemical markers for tracing production, transport, and distribution of a waterborne cue. Mar Ecol Prog Ser 207:283-296

Lenihan HS, Peterson CH, Allen JM (1996) Does flow speed also have a direct effect on growth of active suspensionfeeders: an experimental test on oysters. Limnol Oceanogr 41:1359-1366

Menge BA (1976) Organization of the New England rocky intertidal community: role of predation, competition and environmental heterogeneity. Ecol Monogr 46:355-393

Menge BA (2000) Recruitment versus postrecruitment processes as determinants of barnacle population abundance. Ecol Monogr 70:265-288

Metaxas A, Scheibling RE, Young CM (2002) Estimating fertilization success in marine benthic invertebrates: a case study with the tropical sea star Oreaster reticulatus. Mar Ecol Prog Ser 226:87-101

Minchinton TE (1997) Life on the edge: conspecific attraction and recruitment of populations to disturbed habitats. Oecologia 111:45-52

Molenock J (1976) Agonistic interactions of crab Petrolisthes (Crustacea, Anomura). Z Tierpsychol 41:277-294

Morris RH, Abbott DP, Haderlie EC (1980) Intertidal invertebrates of California. Stanford University Press, Stanford, CA

Muller KL, Stamps JA, Krishnan VV, Willits NH (1997) The effects of conspecific attraction and habitat quality on habitat selection in territorial birds (Troglodytes aedon). Am Nat 150:650-661

Mullineaux LS, Fisher CR, Peterson CH, Schaeffer SW (2000) Tubeworm succession at hydrothermal vents: use of biogenic cues to reduce habitat selection error? Oecologia 123:275-284

Nielsen KJ, Franz DR (1995) The influence of adult conspecifics and shore level on recruitment of the ribbed mussel Geukensia demissa (Dillwyn). J Exp Mar Biol Ecol 188:89-98

Pawlik JR (1992) Chemical ecology of the settlement of benthic marine invertebrates. Oceanogr Mar Biol Annu Rev 30:273-335

Peters RH (1983) The ecological implications of body size. Cambridge University Press, Cambridge

Peterson CH (1982) The importance of predation and intraand interspecific competition in the population biology of two infaunal suspension-feeding bivalves, Protothaca staminea and Chione undatella. Ecol Monogr 52:437-475

Peterson CH, Andre SV (1980) An experimental analysis of interspecific competition among marine filter feeders in a soft-sediment environment. Ecology 61:129-139

Peterson CH, Black R (1993) Experimental tests of the advantages and disadvantages of high density for two coexisting cockles in a southern ocean lagoon. J Anim Ecol 62: $614-633$

Raimondi PT (1988) Settlement cues and determination of the vertical limit of an intertidal barnacle. Ecology 69:400-407

Raimondi PT, Keough MJ (1990) Behavioral variability in marine larvae. Aust J Ecol 15:427-438

Ray M, Stoner AW (1994) Experimental analysis of growth and survivorship in a marine gastropod aggregation: balancing growth with safety in numbers. Mar Ecol Prog Ser 105:47-59

Sanford E, Bermudez D, Bertness MD, Gaines SD (1994) Flow, 
food supply and acorn barnacle population dynamics. Mar Ecol Prog Ser 104:49-62

Schmitt RJ (1996) Exploitation competition in mobile grazers: trade-offs in use of a limited resource. Ecology 77:408-425

Stamps JA (1988) Conspecific attraction and aggregation in territorial species. Am Nat 131:329-347

Tegner MJ, Levin LA (1983) Spiny lobsters and sea urchins: analysis of a predator-prey interaction. J Exp Mar Biol Ecol 73:125-150

Toonen RJ, Pawlik JR (2001a) Foundations of gregariousness: a dispersal polymorphism among the planktonic larvae of a marine invertebrate. Evolution 55:2439-2454

Toonen RJ, Pawlik JR (2001b) Settlement of the gregarious tube worm Hydroides dianthus (Polychaeta: Serpulidae). I. Gregarious and non-gregarious settlement. Mar Ecol Prog Ser 224:103-114

Trager G, Genin A (1993) Flow velocity induces a switch from active to passive suspension feeding in the porcelain crab Petrolisthes leptocheles (Heller). Biol Bull (Woods Hole) 185:20-27

Trager GC, Coughlin D, Genin A, Achituv Y, Gangopadhyay A (1992) Foraging to the rhythm of ocean waves: porcelain crabs and barnacles synchronize feeding motions with flow oscillations. J Exp Mar Biol Ecol 164:73-86

Trager G, Achituv Y, Genin A (1994) Effects of prey escape ability, flow speed, and predator feeding mode on zooplankton capture by barnacles. Mar Biol 120:251-259

Underwood AJ, Denley EJ, Moran MJ (1983) Experimental

Editorial responsibility: Charles Peterson (Contributing Editor), Morehead City, North Carolina, USA analyses of the structure and dynamics of mid-shore rocky intertidal communities in New South Wales. Oecologia 56: 202-219

Wasson K, Lyon BE, Knope M (2002) Hair-trigger autotomy in porcelain crabs is a highly effective escape strategy. Behav Ecol 13:481-486

Wenngren J, Olafsson EB (2002) Intraspecific competition for food within and between year classes in the depositfeeding amphipod Monoporeia affinis-the cause of population fluctuations? Mar Ecol Prog Ser 240:205-213

Werner EE, Gilliam JF (1984) The ontogenetic niche and species interactions in size-structured populations. Annu Rev Ecol Syst 15:393-425

Wing SR, Botsford LW, Largier JL, Morgan LE (1995) Spatial structure of relaxation events and crab settlement in the northern California upwelling system. Mar Ecol Prog Ser 128:199-211

Wing SR, Botsford LW, Quinn JF (1998a) The impact of coastal circulation on the spatial distribution of invertebrate recruitment, with implications for management. Can Spec Publ Fish Aquat Sci 125:285-294

Wing SR, Botsford LW, Ralston SV, Largier JL (1998b) Meroplanktonic distribution and circulation in a coastal retention zone of the northern California upwelling system. Limnol Oceanogr 43:1710-1721

Wootton JT (1993) Size-dependent competition effects on the dynamics versus the end point of mussel bed succession. Ecology 74:195-206

Submitted: July 18, 2003; Accepted: October 10, 2003

Proofs received from author(s): February 12, 2004 